\title{
PELATIHAN TATA KELOLA PEMASARAN PRODUK BERBASIS MOBILE MARKETING UKM INDUSTRI PERAK
}

\author{
Ernani Hadiyati $^{1}$ ), Gunadi ${ }^{2}$ ), Issa Arwani ${ }^{3)}$ \\ ${ }^{1,2)}$ Fakultas Ekonomi dan Bisnis, Universitas Gajayana Malang \\ 3) Fakultas Ilmu Komputer, Universitas Brawijaya Malang. \\ email: ernani_hadiyati@unigamalang.ac.id
}

\begin{abstract}
Abstrak
Program kemitraan masyarakat merupakan salah satu bentuk pengabdian kepada masyarakat yang bertujuan untuk meningkatkan kinerja pengelola UMKM, dalam bidang tata kelola pemasaran produk dan pemasaran berbasis mobile marketing. Target kegiatan ini meliputi: peningkatan kemampuan pengelola UMKM pengrajin perak dalam tatakelola pemasaran produk dan pemasaran berbasis mobile marketing. Luaran yang diharapkan berupa jasa pelatihan, modul dan panduan penerapan tatakelola pemasaran produk dan pemasaran mobile marketing. Metode pelaksanaan menggunakan kombinasi antara pelatihan klasikal, evaluasi, pendampingan dan hibah peralatan untuk menstimulir UMKM pengrajin perak dalam mengimplementasikan materi pelatihan. Hasil pelaksanaan pendampingan menyimpulkan bahwa adanya peningkatan kemampuan dalam tatakelola pemasaran produk dan pemasaran berbasisi mobile marketing maka kinerja pengelola UMKM menunjukkan peningkatan yang signifikan.
\end{abstract}

Kata Kunci : Pelatihan, pendampingan, pemasaran produk, mobile marketing, UMKM

\section{PENDAHULUAN}

Usaha Mikro Kecil dan Menengah (UMKM) di Indonesia sangat besar kontribusinya terhadap recovery kondisi perekonomian bangsa pasca krisis ekonomi tahun 1997 (Hadiyati, 2011). Kontribusi UKM terhadap Product Domestic Brutto (PDB) menjadikan indikator pentingnya UKM dalam peningkatan pertumbuhan perekonomian di Indonesia. Hal ini sesuai data BPS menjelaskan bahwa kontribusi UMKM pada tahun 2007 hingga tahun 2012 menunjukkan peningkatan jumlah PDB UMKM rata-rata sebesar 18.33\%/tahun. Sedangkan pada Usaha Besar (UB) sumbangsih terhadap perkembangan PDB lebih sedikit dibandingkan UMKM, dengan persentase rata-rata perkembangan sebesar $15.75 \%$ per tahun. Data penyerapan tenaga kerja pada tahun 2012 UMKM mampu menyerap 97,16\% dari total tenaga kerja Industri di Indonesia atau sebesar 107.66 juta, sisanya atau sebesar $2.84 \%$ tenaga kerja diserap oleh sektor Usaha Besar (BPS, 2017). Industri perak di Indonesia memiliki keuntungan dari sejarah yang panjang dan infrastruktur yang solid bagi penyediaan bahan baku.Perhiasan dan kerajinan perakdi Indonesia, memiliki keunikan dalam motif ukirannya, di antaranya bermotif bunga ataupun daun maupun motif-motif berciri kesultanan Jogja yang memiliki makna filosofis sendiri, hal ini menandakan tingginya tingkat keahlian dan ketelitian pengrajin perak di Indonesia.

Jawa Timur menjadi salah satu sentra produksi kerajinan perak yaitu wlayah Bangil dan Gempol yang terbesar, namun tetap didukung beberapa wilayah kabupaten yang lain, antar lain Lumajang, Pasuruan dan Mojokerto.Sentra kerajinan perak di Indonesia lainnya adalah Bali dan kerajinan nya memiliki karkateristik tersendiri. Berdasarkan data Biro Pusat Statistik (BPS), ekspor perhiasan perak Bali mencapai $78 \%$ dari total ekspor perhiasan perak Indonesia pada tahun 2011. Diikuti oleh DKI Jakarta, Jawa Timur dan Yogyakarta dengan masing-masing $19,42 \%, 2,64 \%$ dan $0,02 \%$. Secara kuantitas, ekspor Indonesia menurun ditahun 2011 sebesar $11,67 \%$ dari 287 ton menjadi 254 ton.Tahun 2011, BPS mencatat hampir 56\% dari total ekspor perhiasan perak Indonesia ditujukan untuk dua negara tersebut. Nilai ekspor masing-masing yaitu US\$ 22,03 Ribu ke Hong Kong $(28,94 \%)$ dan US\$ 20,54 ribu ke Singapura (26,98\%).Peranan pariwisata sangat tinggi dalam memajukan industri berbasis kerajinan dan UKM, demikian juga sebaliknya.

Peluang ini akan memberikan harapan yang besar kepada UMKM sentra industri perak di 
Indonesia. Namun demikian ssampai saat ini UMKM masih dihadapkan pada sejumlah permasalahan dan berdasarkan dari data survei Januari- Maret tahun 2016 frekuensi persentase permasalahan dengan $\mathrm{N}=100$ dengan hasil meliputi : pemasaran (38\%), permodalan $(27 \%)$, bahan baku (2\%), manajemen pembukuan keuangan (8\%), legalitas usaha (10\%), tenaga kerja (8\%),inovasi (4\%) dan packaging (3\%). Untuk lebih jelasnya permasalahan UMKM dapat dilihat pada gambar 2. Pemasaran merupakan masalah yang memiliki persentase paling tinggi yaitu 38\% (Hadiyati, E 2017).

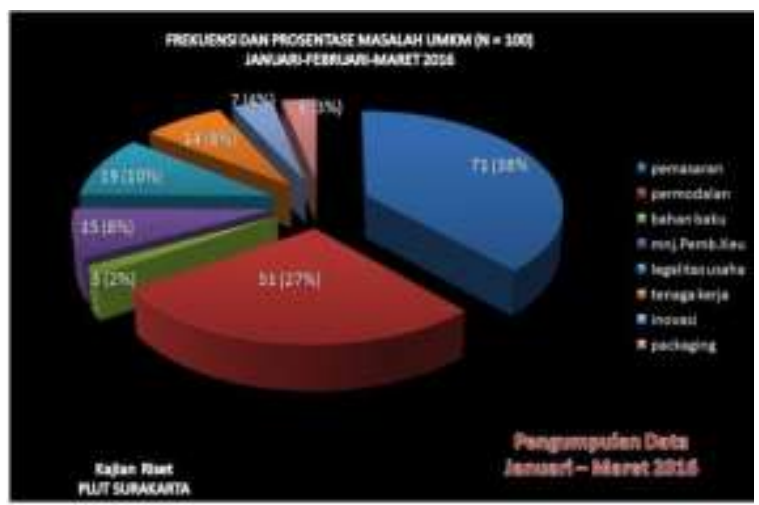

Sumber: Kajian Riset PLT Surakarta,2016

Gambar 1 Frekuensi Persentase Masalah UMKM

Situasi pemasaran dengan persaingan yang semakin ketat, perusahaan juga dituntut adanya tata kelola sistem pemasaran yang berbasis online, (Kumar;Raheja. 2012). Pasar bisnis dan konsumen memiliki banyak kesamaan dan kedua jenis pasar berupaya untuk menciptakan hubungan yang menguntungkan dengan pelanggan denganmenciptakan nilai pelanggan yang luar biasa (Kotler \& Armstrong, 2010). Semakin meningkatnya persaingan telah mempengaruhi harga produk yang ada di pasar. Perusahaan mencoba untuk menjual produknya dengan harga yang lebih murah daripada pesaingnya (Kotler \& Pfoertsch, 2006).

Dalam konteks tersebut pengrajin perak yang akan menjadi mitra dalam Program Kemitraan Masyarakat (PKM) yang memiliki peranan strategis dalam penyediaan lapangan kerja di Pedesaan. Peranan usaha kerajinan ini cukup signifikan dalam menyerap tenaga kerja pada penduduk di wilayah desa Gesang kecamatan Tempeh Kabupaten
Lumajang. Sebagian besar masyarakat di desa Gesang Kecamatan Tempeh ini menggantungkan mata pencahariannya pada usaha kerajinan perak, sehingga keberadaan usaha kecil menengah (UKM) sangat membantu dalam upaya penanggulangan kemiskinan dan pemerataan pendistribusian pendapatan masyarakat. Kondisi tersebut sangat mendukung kondisi perkembangan perekonomian Desa Gesang dan kecamatan Tempeh. Hasil pre survei di wilayah desa Gesang Kecamatan Tempeh tersebut mata pencaharian penduduknya meliputi : pengrajin perak $30 \%$, petani $35 \%$, pegawai $10 \%$ dan sisanya lain-lain 25\%. (Badan Pusat Statistik 2015). Untuk lebih jelasnya data dapat dilihat pada Gambar 2.

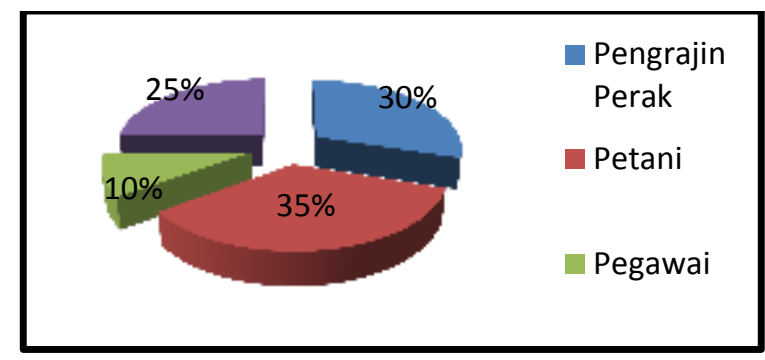

Sumber : Kabupaten Lumajang dalam Angka,2015

Gambar 2 Mata Pencaharian Penduduk Desa Gesang, Kec. Tempeh, Kab. Lumajang

Pada Gambar 2 menunjukkan bahwa jumlah penduduk $30 \%$ mata pencaharian sebagai pengrajin perak memiliki peranan penting sebagai katub pengaman dalam menanggulangi kemiskinan penduduk di desa Gesang Kecamatan Tempeh Kab. Lumajang. Jumlah unit usaha pengrajin perak 37 unit usaha dengan penyerapan tenaga kerja yang berjumlah 359 orang. (Disperindag Kab. Lumajang, 2014).

Bentuk dan jenis-jenis kerajinan perak yang diproduksi oleh perajin Desa Gesang dewasa ini sangat beragam antara lain : anting-anting, liontin, bross, gelang, kalung, tempat lilin, tempat tisu, dan berbagai bentuk cendramata (souvenir) untuk memenuhi kebutuhan pariwisata, baik domistik maupun asing. Produk kerajinan perak tersebut di disain dengan memadukan unsur-unsur motif tradisional yang sudah ada sebelumnya, dengan menyerap unsur-unsur disain modern, sehingga menghasilkan berbagai produk yang kreatif dan 
inovatif, yang memiliki kekhasan tersendiri, sehingga bisa bersaing di pasaran, baik lokal, nasional, maupun global. Kemampuan dalam mengorganisasikan elemen-elemen seni rupa seperti garis, bidang, warna, tektur, ruang, dan prinsipprinsip penyusunan seperti: komposisi, proporsi, kesatuan, kontras, irama, dan keseimbangan, sangat dibutuhkan dalam membuat rancangan disain. Disain yang inovatif memiliki dasar kreatif dalam mencermati gejala sosial, budaya, ekonomi dari masyarakat, sehingga memiliki karakteristik atau identitas budaya, (Armiyati, Laily, 2014). Perajin perak Desa Gesang terus melakukan berbagai upaya dalam mengembangkan disain-disain baru yang kreatif dan inovatif, dalam memenuhi kebutuhan pasar yang sangat kompetitif.

Sedangkan jumlah tenaga kerja yang terlibat pada masing-masing usaha kerajinan perak tergantung dari skala usaha, omzet dan kapasitas produksinya. Secara rata-rata usaha kerajinan perak berdasarkan hasil pra survey terhadap 37 pengusaha telah melibatkan tenaga kerja rata-rata 5 orang karyawan. Jumlah unit usaha yang melibatkan sejumlah 5-9 orang berjulah 33,43\%. Hasil data pra survei menunjukkan bahwa karyawan yang terlibat pada industri kerajinan perak adalah penduduk yang berasal dari desa Gesang, Kec. Tempeh, Kab. Lumajang.

Untuk kelangsungan bisnis kerajinan perak yang lamanya usaha lebih dari 15 tahun menunjukkan persentase paling besar (45,95\%). (Diperindag Kab. Lumajang, 2014).Dari kondisi ini menjelaskan bahwa UKM ini memiliki ketangguhan dalam menghadapi situasi ekonomi yang tidak stabil. Lamanya usaha dan jumlah tenaga kerja yang digunakan dalam industri kerajinanan perak dapat diketahui jumlah hasil produksi per tahun. Hasil produksi disesuaikan dengan jumlah tenaga kerja dari pengusaha.

Sesuai data yang ada jumlah produksi pengrajin yang memiliki persentase yang paling besar adalah 1-9 kg yang berjumlah 27,20\%. Dari kondisi tersebut menunjukkan bahwa jumlah pengrajin perak memiliki peluang untuk meningkatkan jumlah produksi yang harus diimbangi dengan kemampuan dalam memasarkan produk. Dengan omzet penjulan yang meningkat akan berdampak terhadap jumlah produksi yang semakin meningkat. (Disperindag Kab. Lumajang, 2014)

Situasi lain yang menarik dari pengrajin perak adalah masalah pemasaran. Jangkauan wilayah pemasaran sebagian besar berada di wilayah Jawa Timur, utamanya Surabaya, Malang, Jember dan sebagian kecil wilayah Jawa Tengah serta Bali. Apabila dilihat dari hasil produk kerajinan perak ini sangat menarik, hal ini tentunya masih memiliki potensi pasar yang sangat luas. Perluasan pasar dan strategi penetrasi pasar akan berpengaruh terhadap omzet penjualan dan kinerja usaha yang mampu mendukung keberlanjutan usaha. Untuk lebih mengetahui sebaran wilayah pemasaran kerajinan perak berdasarkan wilayah propinsidapat dilihat pada Gambar 3.

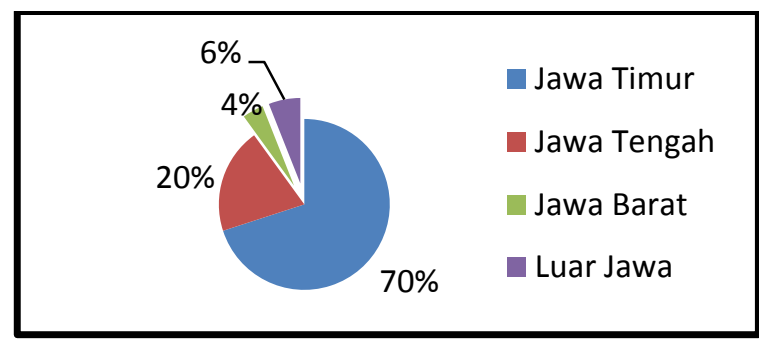

Sumber : Disperindg Kab. Lumajang, 2014.

Gambar 3

Wilayah Pemasaran Kerajinan Perak Desa Gesang

Pada Gambar 3 wilayah pemasaran dengan persentase paling besar $70 \%$ yaitu wilayah Jawa Timur. (Disperindag Kab. Lumajang, 2014). Sebetulnya peluang usaha masih terbuka lebar, apalagi setelah diimplementasikan kebijakan pemerintah dalam memasyarakatkan ekonomi Asia (MEA) merupakan peluang yang membuka potensi pasar kerajinan perak yang cukup luas.

Adapun pertimbangan pemilihan mitra dalam Program Kemitraan Masyarakat (PKM) adalah sebagai berikut :

1. Lokasi mitra merupakan desa yang dikenal dengan desa kreatif dan inovatif sentra UKM yang bergerak dalam usaha yang sama (kerajinan perak) sehingga pelaksanaan pembinaan dan pelatihan akan lebih efektif serta terfokus.

2. UKM kerajinan perak merupakan suatu produk unggulan dari salah satu desa sehingga merupakan bentuk implementasi program 
pemerintah dengan pendekatan One Valage One Product (OVOP).

3. Keahlian pengrajin Perak cukup diperhitungkan dikalangan pengrajin perak pulau Bali yang memiliki akses pasar di pulau dewata dan link pasar properti mancanegara..

4. Usaha tersebut merupakan mata pencaharian dari penduduk setempat sehingga mampu mengurangi jumlah pengangguran.

5. Banyak menyerap tenaga kerja pada masyarakat yang berdomisili di desa dan kecamatan yang sama.

6. Keberadaan usaha tersebut memiliki nilai tambah (value Added) terhadap sektor kelompok usaha yang lain meliputi : toko bahan baku, usaha pengiriman, usaha pengepakan dll.

7. Kelompok UKM kerajinan perak memiliki prospek yang cukup baik, mengingat ketersediaan daya dukung tenaga kerja yang cukup, lokasi yang strategis serta budaya kewirausahaan yang sudah turun temurun,

Kelompok UKM kerajinan perak masih memerlukan pendampingan sebagai bentuk upaya untuk mengatasi masalah sistem pemasaran dalam menggunakan teknologi informasi untuk membantu dan mempermudah dalam perluasan pasar.

\section{METODE KEGIATAN}

UKM kerajinan perak masih menghadapi beberapa kendala yang dominan dalam upaya meningkatkan kinerja nya meliputi : Dalam hal pengelolaan usaha, UKM kerajinan perak yang menjadi mitra masih belum sepenuhnya melaksanakan prinsip manajemen. Tata kelola mulai dari pebuatan desain produk, pengelolaan keuangan dan keseluruhan proses kerja SDM (karyawan) dilaksanakan oleh pemilik juga merangkap manajer. Beban kerja yang terlalu banyak mengakibatkan manajemen atau tatakelola perusahaan akan terganggu. Semua keputusan yang akan diambil tergantung dari pemilik atau manajer. Apabila terjadi suatu fenomena dimana pemilik atau manajer itu bepergian atau jatuh sakit maka efektifitas usaha akan terganggu.. Dengan seiring bertambahnya usia pemilik atau manajer usaha maka penurunan produktivitas akan terjadi dan tentunya berdampak terhadap eksistensi perusahaan.
Sistem pemasaran yang digunakan dengan sistem tradisional.Pengrajin perak masih menggunakan kebiasaan yang lama yang dilakukan oleh para pelaku UKM dikawasan sentra industri tersebut, yaitu sangat bergantung kepada investor/tengkulak yang berasal dari beberapa daerah wilayah pemasarannya. Sebagian besar pengrajin perak belum memiliki pangsa pasar sendiri, order yang dikerjakan umumnya berasal dari investor kerajinan yang memiliki akses pasar di pulau dewata dan link pasar properti mancanegara.Pengrajin lebih memilih menjadi pekerja art shop di pulau bali, sebagian besar hasil produksinya dipasarkan di outlet-outlet khusus kerajinan perak. Pemasaran produk tidak berorientasi pasar melainkan hanya tergantung dari pemesanan investor/tengkulak. Pihak investor/tengkulak akan menentukan desain dan cara pembayaran yang akan dilakukan dalam transaksi jual beli. Pengusaha dalam hal ini tidak mempunyai kemampuan nilai tawar pada saat tengkulak sudah mematok harga maupun sistem pembayarannya. Oleh karena itu persentase keuntungan justru lebih besar diterima oleh pihak tengkulak dari pada pengusaha UKM, karena selama ini tengkulak bebas dalam mempermainkan harga. Selain itu problem yang penting lainnya adalah keterbatasan ketrampilan SDM dalam akses informasi bisnis sehubungan dengan pengembangan usaha dari calon mitra. Selama ini calon mitra untuk mendapatkan informasi tentang strategi bisnisnya hanya melalui kolega, tengkulak atau pedagang grosir yang selama ini dianggap rekanan bisnisnya.

Dalam situasi persaingan yang sangat ketat ini mitra belum pernah memanfaatkan informasi yang berbasis teknologi sehubungan dengan trend model kerajinan perak sesuai dengan kebutuhan pasar atau permintaan konsumen. Apalagi saat ini mitra PKM belum memanfaatkan peluang setelah di implementasikan kebijakan pemerintah dalam menghadapi pasar Asia (MEA).

Sesuai uraian permaslahan, maka masalahmasalah yang dihadapi oleh UMKM pengrajin perak sampai saat ini antara lain:

1. Belum memiliki kemampuan dalam tatakelola pemasaran produk 
2. Belum miliki kemampuan dalam strategi bauran pemasaran.

3. Belum memiliki pengetahuan tentang pemasaran berbasis teknologi informasi.

4. Belum melaksanakan pemasaran berbasis teknologi informasi.

5. Belum memiliki pengetahuan dan kemampuan tentang mobile marketing.

Untuk itu melalui kegiatan PKM ini, diharapkan sebagian permasalahan utama yang dihadapi oleh mitra PKM mendapatkan jalan keluar yang tepat sehingga mampu meningkatkan kinerja usahanya.

\section{HASIL DAN PEMBAHASAN}

Adapaun metode pelaksanaan PKM yang akan dilakukan dalam kegiatan ini meliputi :

1. Persiapan dan Pra Survey

Hasil tahapan ini akan digunakan dasar dalam penyusunan metode pendekatan yang tepat untuk mitra PKM dalam menggunakan teknologi informasi untuk tata kelola usaha dan sistem pemasaran yang lebih efisien dan efektif.

2. Penyusunan Modul

Tahap penyusunan modul dilakukan oleh tim tutorial sesuai dengan kompetensi bidang keilmuan yang dibutuhkan oleh mitra PKM. Modul merupakan acuan bagi mitra PKM dalam memahami dan mengaplikasikan materi pelatihan. Modul akan disusun dengan bahasa yang mudah dimengerti sehingga mudah untuk diimplementasikan oleh mitra PKM.

3. Pelatihan

Tahapan pelatihan dirancang dengan model komunikasi dua arah antara totor dengan mitra PKM. Dalam pelatihan tutor menyampaikan materi pelatihan dengan bahasa lugas sederhana yang mudah dimengerti oleh mitra PKM. Materi pelatihan meliputi bidang :

- Manajemen pemasaran

- Bauran Pemasaran (marketing mix)

- Aplikasi mobile marketing untuk pemasaran produk.

4. Pendampingan.

Tahapan pendampingan merupakan tahapan menindak lanjuti dari kegiatan pelatihan. Tujuan pendampingan adalah untuk meyakinkan kompetensi mitra PKM dalam implementasikan materi pelatihan manajemen usaha, pemasaran dan aplikasi mobile marketing untuk pemasaran produk. Tentunya dalam pendampingan merupakan kegiatan meliputi : konsultasi, monitoring serta evaluasi. Skedul pendampingan dilakukan setiap bulan secara rutin sesuai batas waktu yang ditentukan sehingga mampu mengevaluasi perkembangan mitra PKM dalam mengimplementasikan materi pelatihan yang disampaikan oleh tutor.

5. Penyusunan Laporan.

Tahap Penyusunan laporan adalah kegiatan untuk menyusun, menuliskan secara sistematis dari tahapan sebelumnya menjadi sebuah tulisan laporan hasil kegiatan PKM sesuai format yang ditentukan.

\section{Diskripsi Pelaksanaan}

Deskripsi kegiatan Program Kemitraan Masyarakat (PKM) yang dipaparkan dalam laporan ini, merupakan rangkaian pelaksanaan kegiatan mulai dari tahap survey pendahuluan, pelaksanaan pelatihan, evaluasi pelatihan dan pendampingan implementasi materi pelatihan. Adapun pemaparan secara lengkap masing-masing tahapan pelaksanaan PKM adalah sebagai berikut.

1. Peninjauan lokasi Pengabdian.

Peninjauan lokasi pengabdian dilaksanakan pada tanggal 10 Maret 2018. Lokasi mitra merupakan desa yang dikenal dengan desa kreatif dan inovatif sentra UKM yang bergerak dalam usaha yang sama (kerajinan perak) sehingga pelaksanaan pembinaan dan pelatihan akan lebih efektif serta terfokus.Usaha kecil Industri Perak ini terletak di desa Gesang Kecamatan Tempeh Kabupaten Lumajang.

2. Survey awal Pengabdian.

Pelaksanaan survey awal pengabdian pendahuluan dilaksanakan pada 25 Maret 2018. Pada survey ini berhasil mendeskripsikan kegiatan pengelolaan UKM oleh mitra kerja dan juga mengidentifikasi sejumlah problematika bidang pemasaran yang dihadapi UKM Mitra kerja dan perlu segera dicarikan solusi guna meningkatkan kemampuan dalam strategi 
pemasaran usaha. Adapun beberapa informasi penting yang berhasil didentifikasi dari UKM mitra kerja adalah sistem pemasaran yang digunakan dengan sistem tradisional.Pengrajin perak masih menggunakan kebiasaan yang lama yang dilakukan oleh para pelaku UKM dikawasan sentra industri tersebut, yaitu sangat bergantung kepada investor/ tengkulak yang berasal dari beberapa daerah wilayah pemasarannya.Pemasaran produk tidak berorientasi pasar melainkan hanya tergantung dari pemesanan investor/tengkulak. Pihak investor/ tengkulak akan menentukan desain dan cara pembayaran yang akan dilakukan dalam transaksi jual beli. Pengusaha dalam hal ini tidak mempunyai kemampuan nilai tawar pada saat tengkulak sudah mematok harga maupun sistem pembayarannya. Oleh karena itu persentase keuntungan justru lebih besar diterima oleh pihak tengkulak dari pada pengusaha UKM, karena selama ini tengkulak bebas dalam mempermainkan harga.

3. Modul Pelatihan

Materi modul pelatihan disusun dengan memperhatikan kebutuhan UKM mitra kerja.Materi modul disusun berdasarkan pada hasil pengamatan maupun wawancara secara mendalam dengan UKM mitra kerja. Modul dirancang sesuai dengan tingkat pengetahuan dan ketrampilan yang dikuasai oleh mitra kerja, sehingga kandungan isi modul dirancang dengan lugas agar mudah untuk dipahami peserta pelatihan.

Modul pelatihan disusun oleh tim pelaksana PKM berdasarkan kebutuhan pengelolaan UKM mitra kerja dan sedapat mungkin mudah untuk dilaksanakan dalam praktek penunjang pemasaran produk usahanya, sehingga kinerja pengusaha dalam mengelola bisnis menjadi lebih baik. Modul ini merupakan acuan bagi UKM mitra kerja dalam meningkatkan pengetahuan dan ketrampilan untuk diterapkan dalam menunjang pemasaran produknya.Modul disusun sesederhana mungkin agar mudah dipahami dan diimplementasikan oleh mitra PKM. Adapun modul pelatihan (terlampir) meliputi: manajemen pemasaran dan pemasaran menggunakan whatspapp business.

4. Hibah Peralatan Proses Mobile Marketing

Untuk mendukung optimalisasi hasil program PKM untuk mitra kerja, maka diperlukan peralatan proses mobile marketing. Peralatan proses mobile marketing ini sangat diperlukan oleh mitra kerja karena dibutuhkan untuk meningkatkan skill dalam proses aplikasi. Hibah peralatan nantinya akan dimanfaatkan oleh pengelola usaha perak dalam melakukan pemasaran hasil produk yang berbasis teknologi informasi. Adapun hibah peralatan proses mobile marketing meliputi : PC Tablet, Print, Modem dan Kabel yang telah diserahkan kepada mitra UKM industri perak pada tanggal 14 April sesuai berita penyerahan peralatan yang dihibahkan kepada masing-masing mitra (terlampir). Untuk lebih jelasnya bukti penyerahan hibah peralatan proses mobile marketing kepada mitra dapat dilihat pada Gambar 4 dan Gambar 5.

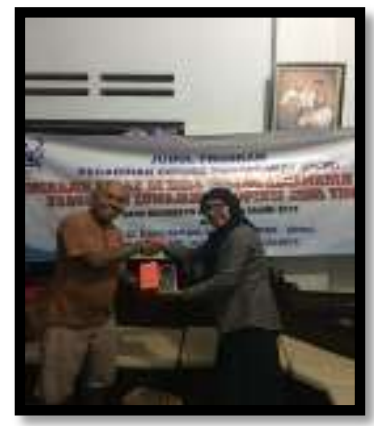

Gambar 4

Penyerahan Hibah Peralatan Proses Mobil Marketing Kepada Mitra ke 1

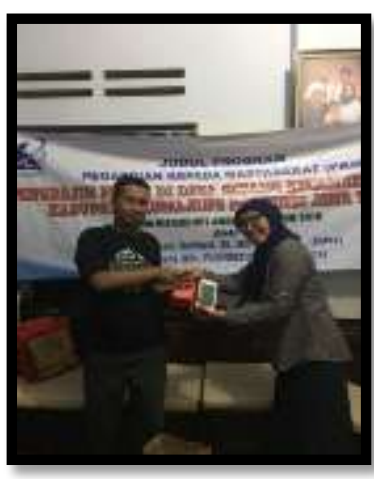

Gambar 5

Penyerahan Hibah Peralatan Proses Mobil Marketing Kepada Mitra ke 2 
Penyerahan peralatan tersebut diharapkan memberikan dukungan kepada mitra untuk mampu memasarkan produknya seiring dengan perkembangan teknologi informasi yang ada pada masyarakat. Peralatan yang dihibahkan juga akan memperlancar dan mengefektifkan pelaksanaan pelatihan yang membutuhkan ketrampilan (skill) dari mitra dalam menggunakan peralatannya. Dalam proses pelatihan, mitra akan diberikan kesempatan untuk bertanya dalam mempraktekkan peralatan dalam proses aplikasi mobile marketing, sehingga akan mampu meningkatkan ketrampilan mitra dalam operasional peralatannya. Ketrampilan yang dimiliki oleh mitra akan mampu mendukung kemandirian mitra dalam mengatasi masalah pemasaran yang selama ini tergantung pada tengkulak.

5. Pelaksanaan Pelatihan

Tahapan lanjutan yang akan dilaksanakan oleh Tim PKM adalah melakukan pelatihan yang diselenggarakan dalam 4kali kegiatanpelatihan pada bulan April 2018. Penentuan Jadwal pelaksanaaan pelatihan tersebut berdasarkan kesepakatan UKM mitra kerja PKM dengan Tim pelaksana.Setelah tahapan pelatihan dilaksanakan, maka tahapan berikutnya adalah melakukan pendampingan kepada mitra kerja yang pelaksanaannya dimulai pada bulan Mei 2018.

Kegiatan pelatihan ini dilakukan langsung ke lokasi usaha mitra kerja dengan jadwal sebagai berikut:

- Pelatihan ke-1 kepada mitra dilak-sanakan pada tanggal 31 Maret sd 01 April 2018.

Pada pelatihan awal ini, tim pelaksana PKM memperkenalkan tentang pengertian dan proses manajemen pemasaran. Selama pelaksanaan pendampingan, tim pendamping PKM memberikan penjelasan materi dan sharing dengan studi kasus langsung pada proses manajemen pemasaran pada industri perak.

- Pelatihan ke-2 kepada mitra dilak-sanakan pada tanggal 14-15 April 2018.
Pada pelatihan kedua, tim pelaksana PKM memperkenalkan pemasaran produk berbasis Teknologi Informasi melalui pendekatan mobile marketing whatsapp for business. Teknologi ini dipilih dengan pertimbangan hasil analisis kebutuhan pengguna dalam menentukan aplikasi mobile marketing yang sesuai dengan bisnis mitra dimana mitra selama ini sudah terbiasa menggunakan aplikasi whatsapp untuk keperluan pribadi. Instalasi dan konfigurasi aplikasi whatsapp for business sekaligus dilakukan pada pelatihan kedua ini.

- Pelatihan ke-3 kepada mitra dilak-sanakan pada tanggal 21 April 2018.

Pada pelatihan ketiga, tim pelaksana PKM mulai memandu peserta untuk segera mengimplemen-tasikan Aplikasi mobile marketing whatsapp for business untuk pemasaran produk. Pelatihan dimulai dengan membuat informasi produk yang siap dipasarkan. Informasi produk yang telah dibuat kemudian dipasarkan menggunakan fitur yang ada di whatsapp for business kepada pelanggan yang sudah menjadi mitra bisnis.

- Pelatihan ke-4 kepada mitra dilak-sanakan pada tanggal 28 April 2018.

Pada pelatihan terakhir, tim pelaksana PKM menekankan pada pentingnya pengelolaan komunikasi dengan rekan bisnis dan pelanggan. Untuk mengimplementasikannya pada aplikasi whatsapp for business, peserta pelatihan diajarkan cara membuat dan mengkonfigurasi fitur Away Message yang digunakan untuk membantu pelaku bisnis tetap terhubung ke konsumen ketika mereka tidak sedang di tempat atau layanan sedang tutup.

6. Evaluasi Pelaksanaan Pelatihan

Evaluasi dilaksanakan dengan cara mewawancarai peserta untuk mengetahui keefektifan pelaksanaan pelatihan maupun berbagai hal yang terkait dengan pelaksanaanya, seperti jadwal pelatihan, metode pelatihan, 
penguasaan instrukstur terhadap materi sampai tingkat kemanfaatan dan tindak lanjut pelatihan itu sendiri. UMKM mitra kerja memberikan tanggapan positif terhadap kegiatan PKM dan merasa memperoleh manfaat dari kegiatan ini bagi upaya meningkatkan kemampuan pemasaran dalam memberikan layanan yang baik kepada pelanggan. Kegiatan pelatihan ini dirasakan telah memberikan nilai tambah bagi pengusaha pengerajin perak, utamanya dalam bidang pemasaranyang baik.Respon positif dari UMKM mitra kerja ini disertai pula dengan keinginan mereka kemukakan agar ada tindak lanjut pelatihan dalam bentuk bantuan konsultasi, baik dalam penerapan materi pelatihan maupun pemecahan masalah.

7. Pendampingan

Kegiatan pendampingan merupakan bagian yang tidak terpisahkan dari kegiatan pelaksanaan PKM. Kegiatan pendampingan dilakukan sebagai instrument monitoring, pemanduan dan sharing secara langsung kepada UKM mitra kerja dalam menerapkan hasil pelatihan yang telah mereka peroleh. Dalam pendampingan ini kegiatannya meliputi:

- Konsultasi dan bimbingan tentang manajemen pemasaran produk.

- Konsultasi dan bimbingan dalam mengimplementasikan teknis penggunaan aplikasi whatsapp business dalam pemasaran dan pelayanan kepada pelanggan.

Kegiatan pendampingan dalam bentuk kunjungan langsung ke lokasi usaha mitra kerja, dilaksanakan dengan jadwal sebagai berikut.

- Pendampingan 1 kepada mitra dilaksanakan pada tanggal1-2Mei 2018.

Pada pendampingan awal ini, tim pelaksana PKM masih memfokuskan pada penjelasan kembali secara mendalam tentang materi pelatihan yang belum dipahami oleh mitra kerja, utamanya tentang penerapan manajemen pemasaran dan proses pemasaran berbasis teknologi informasi dengan mobile marekting. Selama pelaksanaan pendampingan, tim pendamping PKM memberikan penjelasan materi melalui praktek langsung pada point materi yang belum dipahami oleh mereka. Mitra kerja PKM masih merasa kesulitan dalam mengaplikasikan materi pemasaran dengan berbasis mobile marketing.

- Pendampingan 2 kepada mitra dilaksanakan pada tanggal 19Mei 2018.

Pada pendampingan ini, tim pelaksana PKM memonitor tentang konsistensi UKM mitra dalam menerapkan manajemen pemasaran dan mengaplikasikan mobile marketing dalam memberikan pelayanan kepada konsumen. Pada kunjungan kali ini sudah banyak kemajuan pada UKM mitra kerja dalam mengimplemen-tasikan materi pelatihan utamanya praktekaplikasi mobile marketing. Pendampingan dilaksanakan mulai jam 10.30 s.d jam 17.00 dimana pada saat pendampingan dilaksanakan, tim pelaksana PKM banyak memberikan masukan kepada mitra kerja tentang. Pelayanan yang cepat kepada konsumen dengan menggunakan mobile marketing, hal ini karena mitra secara langsung dapat komunikasi dengan konsumen sehubungan dengan pembelian produk yang dihasilkan. Pendamping juga menjelaskan bahwa perlunya profesional dalam kegiatan bisnis karena hal ini sangat berpengaruh terhadap kepercayaan konsumen.

Selama pelaksanaan pendamping-an dan monitoring, tanggapan mitra kerja cukup baik, hal ini terbukti dari banyaknya pertanyaan maupun pernyataan tentang penerapan materi pelatihan. Intensitas pertanyaan terfokus pada teknis operasional aplikasi mobil marketing. Kondisi ini menjadikan suasana pendampingan berlangsung komunikatif dikarenakan tim pendamping dengan UKM mitra kerja terlibat dalam diskusi yang intensif seputar masalah penerapan materi pelatihan yang telah diterima, pengalaman menjalankan usaha, berbagai kendala dalam mengimplementasikan materi pelatihan. Dengan demikian, melalui kegiatan pendampingan ini, Tim pelaksana PKM dapat mengetahui kondisi sebenarnya yang 
dialami oleh UKM baik yang terkait dengan penerapan materi pelatihan maupun kegiatannya dalam pengelolaan pemasaran roduk.

\section{Pembahasan}

Sebagaimana telah dikemukakan pada paparan sebelumnya, bahwa pelaksanaan pengabdian kepada masyarakat skema ProgramKemitraan Masyarakat (PKM) bagi UKM pengerajin perak ini diharapkan dapat meningkatkan kinerja pengelola utamanya dalam pemasaran dan pelayanan kepada konsumen.Untuk dapat membuahkan hasil yang diharapkan, memerlukan rangkaian kegiatan yang disusun secara sistematis baik metode pelatihan, materi yang disampaikan maupun metode pendampingannya. Ketiga rangkaian kegiatan tersebut perlu disesuaikan dengan kondisi obyektif yang selaras dengan kebutuhan mitra kerja agar mudah dipahami dan diimplementasikan.

Pada tahap awal pelaksanaan pelatihan, intruktur menyampaikan tentang urgensi dan manfaat pelatihan bagi upaya memperbaiki pemasaran dan pelayanan usaha.Penjelasan awal ini dipandang penting untuk membuka wawasan berpikir mitra kerja yang selama ini terbiasa mengelola pemasaran dengan sistem tradisional.Pada tahap ini sudah nampak respons positif dari peserta yang ditunjukkan dengan kesungguhan dalam mengikuti seluruh sesi pelatihan. Mereka menjadi pembelajar aktif yang secara antusias mengikuti proses pelatihan maupun pendampingan. Suasana pelatihan yang cukup kondusif ini, sangat membantu bagi instruktur untuk membangun komunikasi timbal balik dalam upaya memberikan penjelasan mendalam atas materi yang diberikan.

Dari sudut pandang normatif, aktivitas pelatihan seyogyanya dapat mengubah sistem berpikir dan prilaku individu peserta latihan.Namun secara faktual bisa jadi berbeda.Perubahan sistem berpikir maupun prilaku individual peserta latihan terkadang bergerak agak lamban dan kurang sebangun dengan yang diharapkan.Kelambanan peserta dalam menginternalisasi materi pelatihan, disebabkan ada kesenjangan pengetahuan dan pengalaman antara instruktur dengan peserta
latihan.Peserta latihan lebih banyak bertumpu pada pengalaman empiris selama mengelola usaha, sementara instruktur terkadang terjebak pada aspek teoritis-normatif.

Kesejangan tersebut munculbukan terletak pada kualitas SDM yang rendah, melainkan lebih pada kurangnya pengetahuan tentang manfaat metode pemasaran yang berbasis teknologi informasi melalui mobile marketing whatsapp business.Hal ini pengusaha juga menyadari bahwa mengelola usaha secara professional sangat diperlukan bagi peningkatan kinerja bisnis ditengah persaingan yang ketat.Mereka paham benar bahwa usaha yang mereka kelola menghadapi persaing yang ketat.Kondisi tersebut membutuhkan komunikasi yang lancar dengan mitra kerja agar proses transformasi pengetahuan dan ketrampilan berlangsung efektif guna meningkatkan kemampuan pengelola pengerajin perak.

Upaya untuk memahamkan peserta pelatihan dalam menerapkan materi bukanlah pekerjaan sederhana, karena mereka sudah terbiasa menerapkan pengelolaan usaha secara tradisional yang telah terbukti berhasil. Untuk itu, tim pelaksana PKM secara terus menerus dalam setiap kunjungan lapangan ataupun melalui kontak telpon berusaha memberi panduan kepada mitra kerja UKM atas materi yang belum dipahami.

Pada tahap pendampingan, tim melaksanakannnya melalui 2 kali kunjungan kelokasi mitra kerja. Pendampingan dengan kunjungan langsung ini bertujuan agar dapat memantau secara langsung perkembangan kemampuan mitra kerja dalam menerapkan materi pelatihan. Selama melakukan pendampingan, tim PKM memfokuskan pada pemanduan tatacara menerapkan materi yang belum dipahami utamanya pemasaran berbasis teknologi informasi dengan pendekatan mobile marketingwhatsapp business.Materi ini memang memerlukan perhatian khusus selama pendampingan berlangsung, hal ini disebabkan peserta pelatihan masih belum dapat menerapkan secara optimal dikarenakan keterbatasan waktu untuk mempelajarinya. Upaya pelaksanaan PKM melalui pelatihan, pendampingan kepada pengelola UKM diharapkan dapat mengoptimalkan pengelola UKM dalam mengelola 
usahanya menjadi lebih baik agar bisnis yang telah ditekuni selama ini dapat tetap survive bahkan berkembang lebih maju.

\section{KESIMPULAN DAN SARAN}

\section{Kesimpulan}

1. UKM industri perak sebagai mitra kerja merespons positif pelaksanaan kegiatan PKM; hal ini ditunjukkan dengan keterlibatan secara aktif selama pelaksanaan pelatihan dengan kesediaan untuk mengikuti keseluruhan tahapantahapan pelatihan.

2. UKM industri perak sebagai mitra kerja berpartisipasi aktif dalam tahap evaluasi, konsultasi dan pendampingan melalui kesediaan untuk mengimplementasikan materi yang telah didapatkan pada saat pelatihan dan juga mengungkapkan hambatan yang dihadapai dalam implementasi materi tersebut.

3. Target kegiatan PKM dapat tercapai, hal ini ditunjukkan adanya peningkatan (skill) dari pengusaha UKM sebagai mitra dalam mengelola pemasaran dan mampu mengoperasionalkan proses mobile marketing watchapp business sehingga mampu mengatasi masalah pemasaran yang selama ini sangat bergantung kepada tengkulak dan bersifat tradisional.

\section{Saran}

1. Agar pelaksanaan pengabdian kepada masyarakat skema PKM bagi UKM sebagai mitra kerja dapat mencapai sasaran, maka perlu pendekatan secara fleksibel; dalam artian metoda pelatihan, jalinan komunikasi maupun metoda pendampingan dikondisikan tidak terlalu formal serta ada kesediaan untuk menyesuaikan jadwal pelatihan maupun pendampingan dengan waktu luang mitra kerja.

2. Setelah pelatihan terhadap UKM dilaksanakan, perlu ada tindak lanjut untuk melakukan pendampingan terhadap mitra kerja agar mereka dapat secara konsisten melakukan tatakelola pemasaran dengan baik serta mampu mengikuti perkembangan teknologi informasi di masyarakat dalam kegiatan pemasaran.

3. Untuk melakukan pembinaan lanjutan terhadap UKM industri perak, perlu dilakukan kajian awal yang mendalam guna menentukan skala prioritas materi maupun metoda pembinaan yang sesuai untuk dilaksanakan.

4. Tim pelaksana hendaknya berperan sebagai fasilitator agar proses pelatihan maupun pendampingan kepada UMKM dapat berjalan efektif.

\section{REFERENSI}

Armiyati, Laily (2014).Industri Perak Kotagede Yogyakarta Melawan Badai Krisis. Sejarah Dan Budaya, Tahun Kedelapan, Nomor 2, Desember.halm. 165-175.

Badan Pusat Statistik (2017). Perkembangan UMKM pada Periode 1997-2013. https://www.bps.go.id/linkTabelStatis/view/id/1 $\underline{322}$

Badan Pusat Statistik (2015). Kabupaten Lumajang Dalam Angka. https://lumajangkab.bps.go.id/index.php/publik asi/48

Buiga, A (2013). Brand Management in Business to Business Markets - Particularities of Business to Business Markets, Branding and Brand Equity -Revista 200 Română de Statistică Supliment Trim II/201.

Diperindag Kab. Lumajang, (2014). Data UMKM . ttps://umajangkab.go.id/RENSTRA\%202015/D INAS/2015.DEPERINDAG

Direktur Jenderal Pengembangan Ekspor Nasional Kementerian Perdagangan Republik Indonesia (2012).. Membedah Potensi Perak Di Indonesia. Warta Eksport.E-mail: p2ie@kemendag.go.id, Website: djpen.kemendag.go.id

Hadiyati, E (2011). Kreativitas dan Inovasi Berpengaruh Terhadap Kewirausahaan Usaha Kecil. Jurnal Manajemen dan Kewirausahaan. Fakultas Ekonomi Universitas Petra Surabaya, Jawa Timur Indonesia.Vol.13, No.1Halm. 8-16.

(2012). Kreativitas Dan Inovasi Pengaruhnya Terhadap Pemasaran Kewirausahaan Pada Usaha Kecil. Jurnal Inovasi dan Kewirausahaan. Volume 1 No. 3 September Halaman 135-151

(2015). Marketing And Government Policy On MSMEs In Indonesian : Theoretical Framework And Empirical Study.International Journal of Business and Management (IJBM) February 2015, pp. 128- 
141ww.ccsenet.org/journal/index.php/ijbm/issu e/currentPublishing by Canada Center of Science and Education

(2017). Strategi Keunggulan Bersaing Industri Kreatif Dalam Menghadapi MEA. Pidato Ilmiah Pengukuhan Guru Besar Universitas Gajayana Malang. 31 Januari.

Kotler, P. Armstrong, G, Principles of Marketing (2010). Pearson Education Inc. NewJersey.
Kotler, P. Pfoertsch, W (2006). B2B brand management. Springer. Berlin, 2006;

Kumar;Raheja (2012). Business To Business (B2b) And Business To Consumer (B2c) Management. International Journal of Computers \& Technology Volume 3 No. 3, Nov-Dec, www.cirworld.com, pp.447-451 